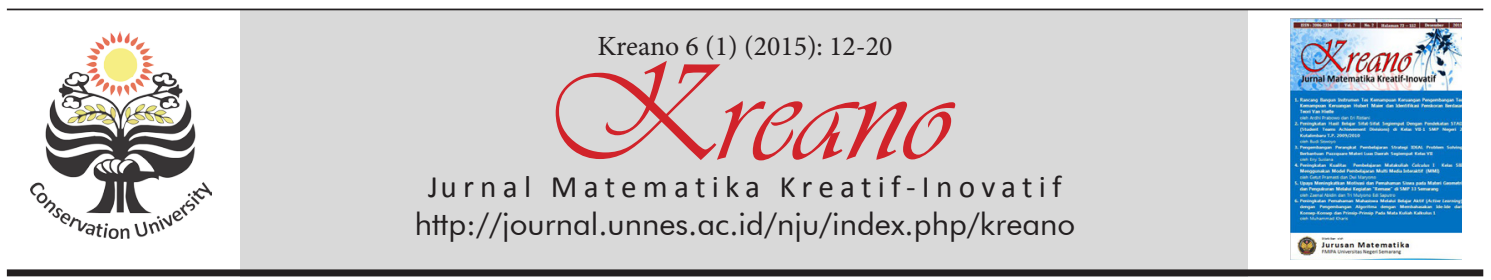

\title{
Pengaruh Model PMK Terhadap Disposisi Matematis dalam Pembelajaran Matematika Tingkat SMA
}

\author{
Nasrullah ${ }^{1}$ \\ 'Jurusan Matematika Universitas Negeri Makassar \\ Email:1nasrullah.niswar@gmail.com \\ DOI: http://dx.doi.org/10.15294/kreano.v6i1.3340 \\ Received : August 2015; Accepted: September 2015; Published: September 2015
}

\begin{abstract}
Abstrak
Penelitian ini bertujuan untuk mengetahui sejauh mana pengaruh model pembelajaran pemecahan masalah kreatif (PMK) terhadap disposisi matematis siswa sekolah menengah atas, dan membandingkannya dengan model pembelajaran langsung ( $\mathrm{PL}$ ). Penelitian ini tergolong eksperimen semu (quacy experiment) dimana subjek penelitian siswa di SMA Muhammadiyah 1 Unismuh. Hasil penelitian menunjukkan tidak berubahnya disposisi matematis siswa seiring perubahan model pembelajaran disebabkan kurangnya keaktifan siswa untuk terlibat dalam membangun kompetensi strategis. Skor disposisi matematis antara model PMK dan PL secara bersama-sama termasuk dalam kategori sedang, tetapi dengan skor 57,89\% yang dicapai oleh model PL mengungguli model PMK dengan skor 42,1 1\%. Dengan kata lain, sebagian besar siswa masih cenderung tertarik dengan model lama. Namun, dengan model PMK justru mampu mendongkrak hasil belajar matematika siswa ditunjukkan dengan besar persentase yaitu 74\%, sedangkan dengan model PL sebesar 58,33\%.
\end{abstract}

\begin{abstract}
This study aims to understand how far the influence of model of learning creative problem solving (CPS) toward mathematical disposition of students in senior secondary school, and compared with model of direct teaching (DT). This research is kind of quacy experiment in which students of SMA Muhammadiyah 1 Unismuh as the research subject. The result of research show that unchangeably mathematical disposition in line with learning model is caused by the lack of students' activeness getting involved in constructing strategic competence. The score of mathematical disposition between CPS together with DT is in the same of middle category, but the score of DT is $57,89 \%$ higher than that of PMK with $42,11 \%$. In the other words, majority of students tend to be interested in the old one. However, CPS model is really able to boost students' achievement indicated by the score of percentage, that is $74 \%$, whereas the percentage of DT is $58,33 \%$.
\end{abstract}

Keywords: Learning Model CPS; Learning Model DT; Mathematical Disposition

\section{PENDAHULUAN}

Pengembangan kegiatan pembelajaran matematika di sekolah tidak hanya diarahkan pada aspek kognitif saja, tetapi juga afektif dan psikomotorik. Di dalam tujuan pembelajaran matematika pada tingkat sekolah dasar dan sekolah menengah, sikap mengapresiasi kegunaan matematika dalam kehidupan sehari-hari, sikap rasa ingin tahu, perhatian, dan minat untuk mempelajari matematika, serta sikap ulet dan percaya diri dalam pemecahan masalah (BSNP, 2006), menjadi tujuan yang ditargetkan dalam suatu kegiatan pembelajaran, termasuk matematika.
Pembelajaran matematika tidak hanya berkaitan tentang pembelajaran konsep, prosedural, dan aplikasinya, tetapi juga terkait dengan disposisi minat dan ketertarikan terhadap matematika (NCTM, 1989). Pengembangan minat dan ketertarikan terhadap matematika tersebut akan membentuk kecenderungan yang kuat yang dinamakan disposisi matematis (mathematical disposition).

Pentingnya disposisi dalam pembelajaran matematika adalah untuk membentuk kecenderungan secara sadar, teratur, dan sukarela berperilaku tertentu yang mengarah pada pencapaian tujuan tertentu bagi pebe- 
lajar matematika. Dalam konteks matematika, disposisi matematis (mathematical disposition) berkaitan dengan bagaimana siswa memandang dan menyelesaikan masalah; apakah percaya diri, tekun, berminat, dan berpikir fleksibel untuk mengeksplorasi berbagai alternatif strategi penyelesaian masalah (Katz dalam Mahmudi, 2010).

Hasil pengamatan awal terhadap aktivitas pembelajaran di kelas XI SMA Muhammadiyah I Unismuh Makassar menunjukkan bahwa selain belum tercapainya standar pencapaian kompetensi yang diharapkan, indikator pengamatan menunjukkan bahwa siswa mudah merasa bosan untuk belajar matematika sedemikian sehingga dianggap bahwa minat mereka agak rendah untuk mempelajari materi pelajaran matematika. Situasi pembelajaran yang tidak mendukung motivasi dan antusias mereka dalam pembelajaran berdampak pada kecenderungan siswa pasif sehingga siswa merasa sulit untuk memahami materi pelajaran matematika yang diberikan.

Berdasarkan laporan TIMSS 2011 mengenai sikap terhadap matematika terlihat bahwa siswa Indonesia yang menyukai belajar matematika masih di bawah rata-rata internasional. Akan tetapi, sikap menyenangi matematika tidak dapat dipandang sebagai keseluruhan dari disposisi matematis. Hal ini dikarenakan disposisi matematis dipandang lebih dari sekedar bagaimana siswa menyenangi matematika (NCTM, 1989). Meskipun sikap menyenangi matematika tidak dapat dipandang sebagai disposisi secara keseluruhan, sikap tersebut dapat dijadikan dasar untuk menumbuhkan sikap positif lainnya, seperti kepercayaan diri, minat terhadap matematika, melihat kegunaan matematika, dan lain-lain.

Katz (dalam Mahmudi, 2010) mendefinisikan disposisi sebagai kecenderungan untuk berperilaku secara sadar (consciously), teratur (frequently), dan sukarela (voluntary) untuk mencapai tujuan tertentu. Perilaku-perilaku tersebut diantaranya adalah percaya diri, gigih, ingin tahu, dan berpikir fleksibel. Dalam konteks matematika, menurut Katz (dalam Mahmudi, 2010) disposisi matematis (mathematical disposition) berkaitan dengan bagaimana siswa menyelesaikan masalah matema- tis; apakah percaya diri, tekun, berminat, dan berpikir fleksibel untuk mengeksplorasi berbagai alternatif penyelesaian masalah. Dalam konteks pembelajaran, disposisi matematis berkaitan dengan bagaimana siswa bertanya, menjawab pertanyaan, mengkomunikasikan ide-ide matematis, bekerja dalam kelompok, dan menyelesaikan masalah.

Untuk mendukung tercapainya proses disposisi yang diharapkan. Menurut Karen (dalam Rosalin, 2008), model Pembelajaran Pemecahan Masalah Kreatif (PMK) adalah suatu model pembelajaran yang berpusat pada keterampilan pemecahan masalah yang diikuti dengan penguatan kreativitas. Dengan model ini diharapkan dapat membangkitkan minat sekaligus kreativitas dan kesenangan siswa dalam mempelajari matematika sehingga hasil belajar memuaskan.

Dibandingkan dengan pembelajaran langsung, menurut

Untuk mengetahui hal tersebut, tulisan ini mengungkapkan perbedaan disposisi matematis yang ditimbulkan bila model PMK atau PL yang diterapkan. Lebih jelasnya, informasi yang berkaitan dikemukakan pada bagian selanjutnya.

\section{METODE}

Untuk melaksanakan kegiatan dari penelitian ini, jenis penelitian quasi eksperimen yang digunakan melibatkan dua kelompok siswa yang diberi perlakuan berbeda. Kelompok pertama mendapat perlakuan model PMK, sedangkan kelompok kedua mendapat perlakuan berupa model pengajaran langsung.

Satuan eksperimen dalam penelitian ini yaitu siswa kelas XI di SMA Muhammadiyah I Unismuh Makassar tahun ajaran 2013/2014 pada semester genap. Sampel ditentukan dengan menggunakan metode purpossive random sampling dengan langkah-langkah: (1) Membentuk 2 kelompok kelas dari seluruh kelas XI SMA Muhammadiyah I Unismuh Makassar. Dalam penelitian ini kelas yang dipilih adalah kelas yang dianggap homogen berdasarkan wawancara dengan guru matematika di sekolah tersebut. (2) Setelah dua kelas terbentuk, kedua kelas tersebut dipilih secara random untuk menentukan kelas eksperimen dan kelas kontrol. Kemudian satu kelas diberi 
perlakuan pembelajaran dengan model pembelajaran Pemecahan masalah kreatif (PMK) yaitu kelas eksperimen dan kelas lain diberi perlakuan dengan model pengajaran langsung yaitu kelas kontrol. Dua jenis perlakuan yang berbeda akan diteliti pengaruhnya. (3) Siswa yang terlibat dari kedua kelas tersebut merupakan satuan eksperimen yang akan diselidiki perlakuannya.

Kegiatan penelitian ini dimulai dengan tahap persiapan dimana peneliti melakukan persiapan perangkat pembelajaran yang akan digunakan dalam melaksanakan proses pembelajaran. Perangkat pembelajaran yang dimaksud meliputi Rencana Pelaksanaan Pembelajaran (RPP), Lembar Kerja Siswa (LKS), tes hasil belajar, lembar keterlaksanaan pembelajaran, dan angket Disposisi matematis.

Kemudian dilanjutkan tahap pelaksanaan dimana penggunaan model pembelajaran PMK untuk kelas eksperimen, dan penerapan model pengajaran langsung untuk kelas kontrol disesuaikan dengan Rencana Pelaksanaan Pembelajaran (RPP) yang telah disusun. Langkah-langkah pembelajarannya adalah seperti pada Tabel 1.

Pengumpulan data dilakukan setelah di- laksanakan proses pembelajaran pada pokok bahasan persamaan lingkaran pada kedua kelompok, dengan langkah-langkah sebagai berikut:

a. Memberikan tes hasil belajar pada kedua kelompok setelah perlakuan. Tes hasil belajar yang digunakan yaitu tes subjektif yang berbentuk essai dengan jumlah soal 5 item yang sebelumnya telah divalidasi oleh validator berkompeten dalam membuat soal-soal pada pokok bahasan persamaan lingkaran.

b. Memberikan angket disposisi matematis pada kedua kelompok sampel setelah diberi perlakuan. Dimana terdapat 30 butir pernyataan yang sebelumnya telah divalidasi.

c. Setelah pengambilan data rampung, jawaban siswa tersebut diperiksa dan diberikan skor.

Dengan demikian, instrumen penelitian yang digunakan dalam penelitian ini adalah lembar keterlaksanaan, lembar observasi, tes hasil belajar, dan angket disposisi matematis. Tes hasil belajar yang digunakan adalah tes yang memuat materi pelajaran matematika. Sedangkan indikator tentang disposisi ma-

Tabel 1. Langkah-langkah Pembelajaran Pemecahan Masalah Kreatif dan Pengajaran Langsung

Pemecahan masalah kreatif (PMK)

1) Guru menyampaikan informasi.

2) Guru menyiapkan LKS yang telah dibuat untuk proses pembelajaran.

3) Guru membentuk kelompok.

4) Guru membagikan LKS kepada masing-masing kelompok. Siswa menyelesaikan masalah-masalah dalam LKS yang diberikan. Guru memberikan waktu kepada siswa untuk menemukan fakta dan menemukan masalah yang ada dalam LKS tersebut.

5) Kemudian siswa diberi kesempatan mengungkapkan gagasan sebanyak-banyaknya mengenai alternatif solusi dari masalah yang diberikan bersama kelompoknya masing-masing.

6) Masing-masing kelompok mempresentasikan hasil kerja kelompoknya dan kelompok lain memberi tanggapan.

7) Guru bersama siswa mengklarifikasi permasalahan yang ada dalam aktivitas tersebut sehingga siswa mengetahui solusi yang diharapkan dari aktivitas tersebut untuk diajukan di kelas.

8) Guru mengarahkan penarikan kesimpulan tentang pemecahan masalah yang optimal dari berbagai pendapat masing-masing kelompok.
Pengajaran Langsung

1) Guru menyampaikan tujuan dan mempersiapkan siswa.

2) Guru mendemonstrasikan keterampilan dengan benar, atau menyajikan informasi tahap demi tahap.

3) Guru memberikan bimbingan pelatihan awal.

4) Guru mengecek pemahaman siswa dengan memberikan umpan balik.

5) Guru memberikan kesempatan untuk pelatihan lanjutan.

\section{UNNES JOURNALS}


tematis ini memuat tujuh komponen yaitu: (1) kepercayaan diri, komunikatif, dan argumentatif; (2) fleksibilitas dalam mengeksplorasi ide-ide matematis dan mencoba berbagai metode alternatif untuk memecahkan masalah; (3) bertekad untuk menyelesaikan tugastugas untuk matematika; (4) keterkaitan, keingintahuan, dan kemampuan untuk menemukan dalam mengerjakan matematika; (5) kecenderungan untuk memonitor dan merefleksi proses berpikir dan kinerja diri sendiri; (6) menilai aplikasi matematika dalam bidang lain dan dalam kehidupan sehari-hari; dan (7) penghargaan (appreciation) peran matematika dalam budaya dan nilainya, baik matematika sebagai alat, maupun matematika sebagai bahasa. Angket disposisi matematis diberikan kepada siswa setelah perlakuan.

Observasi dilakukan di kelas eksperimen dan di kelas kontrol, lembar observasi keterlaksanaan pembelajaran ini digunakan untuk mendapatkan data tentang pencapaian pengajar dalam pemberian perlakuan di dalam kelas, sehingga di dalam pelaksanaan pembelajaran benar-benar sesuai dengan kondisi dan proses yang diharapkan. Konsep dasar penyusunan instrumen observasi dalam hal ini adalah teori dan prosedur pelaksanaan pembelajaran yang digunakan dalam penelitian ini, yaitu penerapan model pembelajaran pemecahan masalah kreatif (PMK) dan Model Pengajaran Langsung.

Untuk teknik analisis data yang digunakan dalam penelitian ini terdiri atas: pertama, analisis Keterlaksanaan Pembelajaran yang dilakukan dengan dua langkah yaitu menentukan frekuensi hasil pengamatan keterlaksanaan pembelajaran untuk setiap kegiatan dalam satu kali pertemuan, dan persentase keterlaksanaan pembelajaran dengan membagi besarnya frekuensi dengan jumlah frekuensi untuk semua indikator, kemudian dikalikan $100 \%$. Sedangkan untuk tes hasil belajar dan disposisi matematis digunakan analisis statistika deskriptif, metode yang digunakan untuk mengumpulkan, mengolah, dan menyajikan data dalam bentuk angka, tabel, atau grafik (Tiro \& B. Ilyas, 2010). Untuk pengkategorisasian, skor hasil belajar siswa dikategorikan secara kualitatif berdasarkan Departemen Pendidikan Nasional oleh (Pur- wanto, 2012) adalah sebagai berikut.

\begin{tabular}{cc} 
Tabel 2. Interpretasi Kategori Nilai Hasil Belajar \\
\hline Nilai Hasil Belajar & Kategori \\
\hline $90-100$ & Sangat Tinggi \\
$80-89$ & Tinggi \\
$65-79$ & Sedang \\
$55-64$ & Rendah \\
$<55$ & Sangat Rendah \\
\hline
\end{tabular}

Untuk keperluan analisis tersebut, disusun suatu kriteria ketuntasan minimal (KKM) siswa dalam belajar yang berlaku di sekolah tempat penelitian, yaitu:

Tabel 3. Kriteria Ketuntasan Minimal (KKM)

\begin{tabular}{cc}
\hline Interval Nilai & Kategori \\
\hline$<70$ & $\begin{array}{c}\text { Tidak Tuntas } \\
\text { Tuntas }\end{array}$ \\
\hline er: SMA Muhammadiyah IUnismuh Makassar
\end{tabular}

Sementara untuk data tentang disposisi matematis diperoleh dari angket mengenai disposisi matematis siswa setelah perlakuan yang menggunakan skala likert. Dalam menggambarkan disposisi matematis siswa setelah perlakuan dalam penelitian ini, digunakan kriteria sebagai berikut.

Tabel 4. Kategori Disposisi Matematis

\begin{tabular}{cc}
\hline Skor Rata-rata & Kategori \\
\hline Skor $<60 \%$ & Sangat Rendah (SR) \\
$60 \% \leq$ Skor $<70 \%$ & Rendah (R) \\
$70 \% \leq$ Skor $<80 \%$ & Sedang (S) \\
$80 \% \leq$ Skor $<90 \%$ & Tinggi (T) \\
Skor $\geq 90 \%$ & Sangat Tinggi (ST) \\
\hline \multicolumn{2}{c}{ Sumber: Sugilar (dalam Muslim, 2013) }
\end{tabular}

\section{HASIL DAN PEMBAHASAN}

Keterlaksanaan pembelajaran yang diobservasi dilihat dari aktivitas guru dalam mengelola pembelajaran pada kelas yang menerapkan model pembelajaran pemecahan masalah kreatif (PMK). Hasil observasi menunjukkan bahwa proses pembelajaran dengan menggunakan model pembelajaran PMK dapat terlaksana dengan persentase sebesar $97,50 \%$.

Dengan kata lain, terdapat satu tahap pembelajaran yang tidak dilaksanakan oleh guru model, yaitu memotivasi siswa dengan menyampaikan kegunaan materi yang akan 
dipelajari. Akan tetapi, hal ini dapat terlihat ketika kegiatan pengamatan dilakukan pada pertemuan kedua dan ketiga.

Sementara itu, untuk kelas yang menerapkan model pengajaran langsung. Berdasarkan observasi yang dilakukan melalui lembar observasi keterlaksanaan pembelajaran, dapat disimpulkan bahwa proses pembelajaran pada kelas yang diajar dengan menggunakan model pengajaran langsung terlaksana sesuai dengan rencana pelaksanaan pembelajaran (RPP) dengan persentase keterlaksanaannya yaitu $96,43 \%$. Berdasarkan hasil observasi pada pertemuan pertama semua tahap pembelajaran terlaksana sesuai dengan RPP yang ada, pertemuan kedua ada satu tahap yang tidak terlaksana yaitu menutup pelajaran dengan salam dan berdoa, sedangkan untuk pertemuan ketiga ada juga satu tahap yang tidak terlaksana yaitu guru memotivasi siswa dengan menyampaikan kegunaan materi yang akan dipelajari dan pertemuan keempat proses pembelajaran secara keseluruhan dilaksanakan sesuai RPP yang ada. Berdasarkan hal tersebut, maka disimpulkan bahwa sebelum dilaksanakannya tes hasil belajar, proses pembelajaran yang dilaksanakan pada kelas kontrol yang diajar dengan menggunakan model pengajaran langsung telah terlaksana sesuai dengan RPP yang ada.

Hasil statistik yang berkaitan dengan skor variabel hasil belajar matematika siswa pada kelas eksperimen yang diajar dengan menggunakan model pembelajaran pemecahan masalah kreatif, jika hasil belajar matematika siswa dikelompokkan ke dalam 5 kategori maka diperoleh distribusi dan persentase sebagaimana terlihat di Tabel 5 .

Tabel 5. Distribusi skor hasil belajar matematika kelompok model PMK

\begin{tabular}{|c|c|c|c|c|}
\hline No & Skor & Kategori & $\mathrm{F}$ & $\%$ \\
\hline 1 & $0-54$ & Sangat Rendah & 0 & $0 \%$ \\
\hline 2 & $55-69$ & Rendah & 5 & $26,32 \%$ \\
\hline 3 & $70-79$ & Sedang & 4 & $21,05 \%$ \\
\hline 4 & $80-89$ & Tinggi & 6 & $31,58 \%$ \\
\hline 5 & $90-100$ & Sangat Tinggi & 4 & $21,05 \%$ \\
\hline \multicolumn{3}{|c|}{ JUMLAH } & 19 & $100 \%$ \\
\hline
\end{tabular}

Tabel 5 menunjukkan bahwa dari 19 siswa kelas XI SMA Muhammadiyah I Unis- muh Makassar, terdapat 14 orang siswa yang memperoleh nilai di atas 70. Dengan kata lain, siswa yang memperoleh nilai dengan kategori sedang, tinggi, dan sangat tinggi masing-masing sebanyak 4, 6, dan 4 orang.

Informasi ini memberikan gambaran bahwa pembelajaran matematika dengan model PMK dapat pencapaian KKM sekitar $74 \%$. Dengan diagram batang, persentase tersebut dapat ditunjukkan ke dalam gambar di bawah ini.

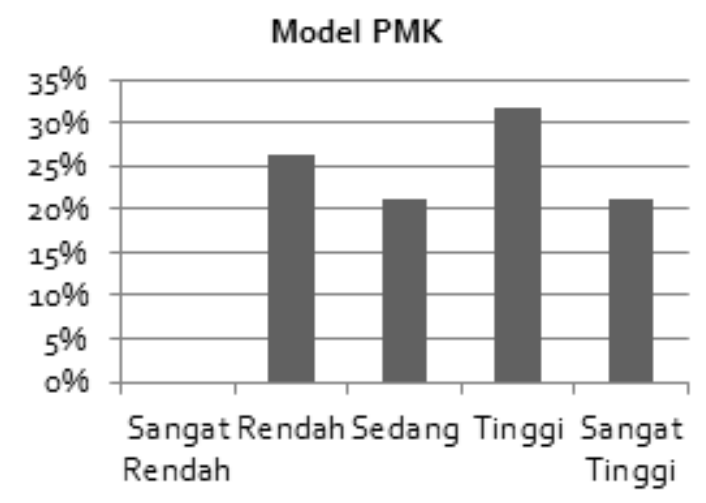

Gambar 1. Diagram Persentase skor hasil belajar matematika siswa yang diajar dengan menggunakan model PMK

Kemudian dibandingkan dengan hasil statistik yang berkaitan dengan skor variabel hasil belajar matematika siswa yang diajar dengan menggunakan model pengajaran langsung dalam tabel berikut:

Tabel 6. Distribusi skor hasil belajar matematika kelompok model PL

\begin{tabular}{|c|c|c|c|c|}
\hline No & Skor & Kategori & $\mathrm{F}$ & $\%$ \\
\hline 1 & $0-54$ & Sangat Rendah & 4 & $16,67 \%$ \\
\hline 2 & $55-69$ & Rendah & 6 & $25,00 \%$ \\
\hline 3 & 70-79 & Sedang & 9 & $37,50 \%$ \\
\hline 4 & $80-89$ & Tinggi & 4 & $16,67 \%$ \\
\hline 5 & $90-100$ & Sangat Tinggi & 1 & $4,17 \%$ \\
\hline \multicolumn{3}{|c|}{ JUMLAH } & 24 & $100 \%$ \\
\hline
\end{tabular}

Tabel 6 menyajikan data yang berbeda jika dibandingkan dengan kelas model PMK. Tabel ini menunjukkan bahwa dari 24 siswa, 10 orang diantaranya tidak memenuhi KKM, sekitar $41,67 \%$. Dengan kata lain, siswa yang memperoleh nilai dengan kategori sedang, tinggi, dan sangat tinggi masing-masing sebanyak 9, 4, dan 1 orang, seluruhnya sebesar $58,33 \%$. 
Informasi ini memberikan gambaran bahwa pembelajaran matematika dengan model PL hanya dapat pencapaian KKM sekitar 58,33\%. Dengan diagram batang, persentase tersebut dapat ditunjukkan ke dalam gambar di bawah ini.

\section{Model PL}

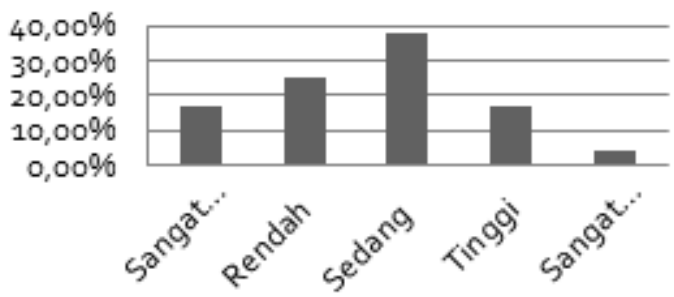

Gambar 2. Diagram Persentase skor hasil belajar matematika siswa yang diajar dengan menggunakan model pengajaran Langsung

\section{Analisis Disposisi Matematis Siswa}

Sesuai dengan data angket yang terkumpul, statistik yang berkaitan dengan skor variabel disposisi matematis pada kelas Model PMK ditunjukkan dalam tabel 7 berikut:

Tabel 7. Distribusi skor posttest disposisi matematis dengan menggunakan model PMK

\begin{tabular}{ccccc}
\hline No & $\begin{array}{c}\text { Skor Rata-rata } \\
(\mathrm{SR})\end{array}$ & $\begin{array}{c}\text { Kate } \\
\text { gori }\end{array}$ & $\mathrm{F}$ & $\%$ \\
\hline 1 & $\mathrm{SR}<60 \%$ & $\mathrm{SR}$ & 0 & $0 \%$ \\
2 & $60 \% \leq \mathrm{SR}<70 \%$ & $\mathrm{R}$ & 3 & $15,79 \%$ \\
3 & $70 \% \leq \mathrm{SR}<80 \%$ & $\mathrm{~S}$ & 8 & $42,11 \%$ \\
4 & $80 \% \leq \mathrm{SR}<90 \%$ & $\mathrm{~T}$ & 7 & $36,84 \%$ \\
5 & $\mathrm{SR} \geq 90 \%$ & $\mathrm{ST}$ & 1 & $5,26 \%$ \\
\hline & $\mathrm{JUMLAH}$ & & 19 & $100 \%$ \\
\hline
\end{tabular}

Pada tabel ini menunjukkan bahwa dari 19 siswa kelas XI SMA Muhammadiyah I Unismuh Makassar, tidak terdapat siswa yang memperoleh nilai sangat rendah, dengan kata lain skor di atas $60 \%$ mencapai $100 \%$. Statistika pada tabel tersebut bila disajikan dalam gambar 3 .

Dari diagram tersebut, skor yang dominan berada pada interval $70 \% \leq \mathrm{SR}<$ $80 \%$ dengan persentase sebesar $42,11 \%$. Sebenarnya, tidak jauh berbeda dengan skor pada interval $80 \% \leq \mathrm{SR}<90 \%$ yang mempunyai persentase sebesar $36,84 \%$.
Namun, siswa yang mempunyai skor dengan kategori rendah masih 3 kali lebih tinggi daripada yang berkategori sangat tinggi.

\section{Persentase}

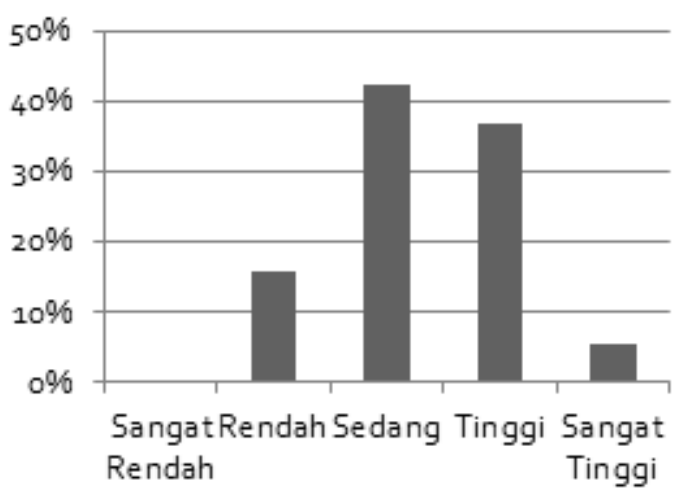

Gambar 3. Persentase Skor Disposisi Matematis Pembelajaran Menggunakan model PMK

Sementara itu, statistik yang berkaitan dengan variabel disposisi matematis yang diajar dengan model PL disajikan dalam tabel berikut:

Tabel 8. Distribusi skor posttest disposisi matematis dengan menggunakan model $\mathrm{PL}$

\begin{tabular}{ccccc}
\hline No & Skor Rata-rata & Kategori & F & $\%$ \\
\hline 1 & Skor $<60 \%$ & SR & 0 & $0 \%$ \\
2 & $60 \% \leq$ Skor $<70 \%$ & R & 1 & $5,26 \%$ \\
3 & $70 \% \leq$ Skor $<80 \%$ & S & 11 & $57,89 \%$ \\
4 & $80 \% \leq$ Skor $<90 \%$ & T & 9 & $47,37 \%$ \\
5 & Skor $\geq 90 \%$ & ST & 3 & $15,79 \%$ \\
\hline & JUMLAH & & 24 & $100 \%$ \\
\hline
\end{tabular}

Pada tabel ini menunjukkan bahwa dari 24 siswa kelas XI SMA Muhammadiyah I Unismuh Makassar, tidak terdapat siswa yang memperoleh nilai sangat rendah, dengan kata lain skor di atas 60\% mencapai 100\%. Statistika pada tabel tersebut bila disajikan ke dalam gambar 4 .

Dari diagram tersebut, skor yang dominan berada pada interval $70 \% \leq \mathrm{SR}<80 \%$ dengan persentase sebesar $57,89 \%$. Sebenarnya, tidak jauh berbeda dengan skor pada interval $80 \% \leq \mathrm{SR}<90 \%$ yang mempunyai persentase sebesar $47,37 \%$. Menariknya, siswa yang mempunyai skor dengan kategori rendah ti- 
dak lebih tinggi daripada yang berkategori sangat tinggi.

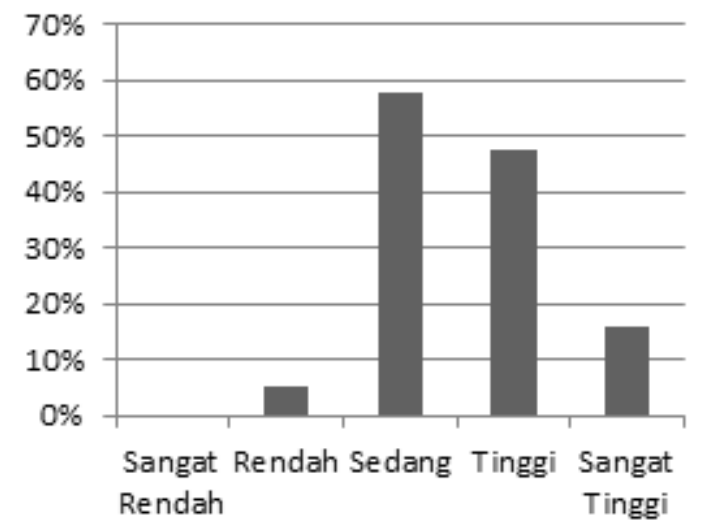

Gambar 4. Persentase Skor Disposisi Matematis Pembelajaran Menggunakan model PL

Sebagai tambahan, sesuai dengan analisis statistika inferensial dapat ditunjukkan bahwa terdapat hubungan yang signifikan antara model pembelajaran dengan hasil belajar matematika, dimana nilai $\mathrm{F}$ sebesar 4,380 dengan signifikansi sebesar $0,043(<\alpha=0,05)$.

Secara signifikan, hal ini mengarahkan bahwa terdapat perbedaan hasil belajar yang diakibatkan oleh perbedaan model pembelajaran. Selanjutnya, jika dilihat dari hasil analisis diperoleh nilai $p$-value < yaitu 0,010< 0,05 yang menandakan bahwa skor rata-rata posttest siswa yang diberi perlakukan dengan model pembelajaran PMK lebih besar dari 70 (KKM).

Selanjutnya untuk hasil analisis tentang hubungan antara model pembelajaran dengan disposisi matematis memberikan harga $\mathrm{F}$ sebesar 0,656 dengan signifikansi 0,423 yang lebih besar daripada taraf signifikansi 0,05. Artinya, tidak terdapat perbedaan disposisi matematis yang diakibatkan oleh perbedaan model pembelajaran. Jadi, dapat disimpulkan bahwa tidak terdapat pengaruh penggunaan model pembelajaran pemecahan masalah kreatif secara signifikan terhadap disposisi matematis siswa kelas XI SMA Muhammadiyah I Unismuh Makassar.

Sebenarnya National Council of Teachers of Mathematics (1989) mengemukakan tujuh komponen dalam disposisi matematika diantaranya, rasa percaya diri, fleksibilitas bermatematika, kegigihan dan keuletan mengerjakan tugas-tugas matematika, rasa ingin tahu dalam bermatematika, merefleksi cara berpikir, menghargai aplikasi matematika, dan mengapresiasi peranan matematika. Komponen-komponen ini dikaitkan dengan tujuan pendidikan matematika sekolah menurut Kurikulum 2006 diantaranya: memiliki sikap menghargai kegunaan matematika dalam kehidupan, yaitu memiliki rasa ingin tahu, perhatian, dan minat dalam mempelajari matematika, serta sikap ulet dan percaya diri dalam pemecahan masalah (Departemen Pendidikan Nasional, 2007, h. 346).

Apabila Kilpatrick, Swafford, dan Findel (2001), menyatakan bahwa disposisi matematika adalah kecenderungan untuk: (i) memandang matematika sesuatu yang dapat dipahami, (ii) merasakan matematika sebagai sesuatu yang berguna dan bermanfaat, (iii) meyakini usaha yang tekun dan ulet dalam mempelajari matematika akan membuahkan hasil, dan (iv) melakukan perbuatan sebagai pebelajar dan pekerja matematika yang efektif.

Secara teoritis, model pembelajaran pemecahan masalah kreatif dan model pengajaran langsung akan memberikan kontribusi terhadap perubahan disposisi matematis siswa dalam kegiatan pembelajaran. Untuk model PMK jarang untuk diterapkan oleh guru di kelas, berbeda dengan model PL. Oleh karena itu, siswa terbiasa dengan aktivitas model PL daripada model PMK. Namun, kemenarikan aktivitas model PMK dapat menstimulasi siswa untuk berbuat lebih kreatif dalam kegiatan pembelajaran.

Penerapan model PMK bertujuan agar disposisi matematika siswa berkembang ketika mereka belajar dan terbangun kompetensi strategis dalam menyelesaikan persoalan non-rutin yang secara bersamaan sikap dan keyakinan mereka sebagai seorang pebelajar menjadi lebih positif. Karena pemberian soal yang tidak biasanya sehingga memicu siswa untuk mengembangkan konsep dan pemahaman yang dimiliki. Makin banyak konsep dipahami oleh seorang siswa, siswa tersebut makin yakin bahwa matematika itu dapat dikuasai. Sebaliknya, bila siswa jarang diberikan tantangan berupa persoalan matematika untuk diselesaikan. 
Dengan asumsi tersebut, model PMK akan memberikan pengaruh positif terhadap disposisi matematis mereka. Walaupun secara statistik tidak cukup signifikan untuk menunjukkan bahwa disposisi matematis siswa dapat berubah dengan model PMK. Bahkan, secara deskriptif diketahui bahwa dengan penerapan model PMK, siswa yang mempunyai skor dengan kategori rendah masih 3 kali lebih tinggi daripada yang berkategori sangat tinggi. Berbeda dengan model PL, siswa yang mempunyai skor dengan kategori rendah tidak lebih tinggi daripada yang berkategori sangat tinggi.

Terdapat dua hal yang dapat menjelaskan sedemikian sehingga PL masih lebih baik daripada PMK, gaya guru untuk mengajar dengan lebih meyakinkan dipengaruhi oleh model PL dan siswa masih nyaman dengan model PL daripada model PMK.

Sejalan dengan yang telah dilakukan oleh Mulyana (2009) tentang MPMK tidak berpengaruh terhadap peningkatan disposisi matematika siswa, demikian pula pada masing-masing level sekolah. Namun demikian, penerapan MPMK diduga berpengaruh baik terhadap peningkatan disposisi siswa, bila dilaksanakan dalam waktu yang cukup panjang.

Asumsi dalam penelitian ini semakin memperkuat bahwa suasana pembelajaran menjadi faktor pembentuk disposisi matematis. Oleh karena itu, perlu waktu untuk mengubah kebiasaan siswa dengan menerapkan model pembelajaran yang tidak biasa diterapkan di dalam kelas. Kemudian perkembangan disposisi matematika akan semakin positif seiring kegiatan siswa yang selalu diberikan lebih banyak kesempatan untuk menguasai matematika, menyadari manfaat ketekunan, dan merasakan keuntungan dari penguasaan matematika (Kilpatrick, Swafford, dan Findell, 2001).

Tuntutan model pembelajaran pemecahan masalah kreatif adalah siswa dituntut untuk selalu aktif selama pembelajaran berlangsung, yakni aktif untuk menemukan solusi dari masalah secara kreatif, juga aktif berinteraksi dengan siswa lain melalui kegiatan diskusi kelompok maupun diskusi kelas, siswa tidak hanya sekedar menerima secara pasif informasi yang ditransfer oleh guru, tetapi siswa berperan aktif dalam menggali informasi yang dibutuhkan sesuai dengan indikator pembelajaran yang telah ditetapkan. Namun, situasi pembelajaran seperti ini belum sepenuhnya tepat menginspirasi siswa mengikuti kegiatan pembelajaran sebagaimana yang diharapkan.

\section{SIMPULAN}

Berdasarkan hasil penelitian dan pembahasan kesimpulan penelitian ini dapat dikemukakan sebagai berikut.

Tidak berubahnya disposisi matematis siswa seiring perubahan model pembelajaran disebabkan kurangnya keaktifan siswa untuk terlibat dalam membangun strategic competence. Akibatnya siswa cenderung menjadi menghafal dari pada mengikuti cara-cara belajar matematika yang semestinya, dan mereka mulai kehilangan rasa percaya diri sebagai pebelajar.

Skor disposisi matematis antara model pembelajaran pemecahan masalah kreatif dan pengajaran langsung secara bersamasama termasuk dalam kategori sedang, tetapi dengan skor $57,89 \%$ yang dicapai oleh model pengajaran langsung mengungguli model pembelajaran pemecahan masalah kreatif dengan skor $42,11 \%$. Dengan kata lain, sebagian besar siswa masih cenderung tertarik dengan model lama.

Dengan model pembelajaran pemecahan masalah kreatif justru mampu mendongkrak hasil belajar matematika siswa ditunjukkan dengan besar persentase yaitu $74 \%$, sedangkan dengan model pengajaran langsung sebesar $58,33 \%$.

Penelitian ini merekomendasikan saran untuk sekolah agar mempersiapkan program peningkatan disposisi matematis siswa. Selain untuk pengembangan sikap peserta didik dalam kegiatan pembelajaran, juga untuk mendongkrak kemampuan internal peserta didik. Ketika siswa merasa dirinya kapabel dalam belajar matematika dan menggunakannya dalam memecahkan masalah, mereka dapat mengembangkan kemampuan keterampilan menggunakan prosedur dan penalaran adaptifnya. Disposisi matematika siswa merupakan faktor utama dalam menentukan kesuksesan pendidikan selanjutnya. 
20 Nasrullah, Pengaruh Model PMK Terhadap Disposisi Matematis dalam Pembelajaran Matematika...

\section{DAFTAR PUSTAKA}

BSNP. (2006). Standar Kompetensi dan Kompetensi Dasar SMP/MTs. Jakarta: Balitbang.

Departemen Pendidikan Nasional (2007). Peraturan Menteri Pendidikan Nasional Republik Indonesia No. 41 Tahun 2007 tentang Standar Proses untuk Satuan Pendidikan Dasar dan Menengah. Tersedia: http://www.bsnp-indonesia.org/standardsproses.ph

Kilpatrick, J.,Swafford, J.,\& Findell, B. (2001). Adding It Up: Helping Children Learn Mathematics. Washington, DC: National Academy Press.

Mahmudi, A. 2010. Tinjauan Asosiasi antara Kemampuan Pemecahan Masalah Matematis dan Disposisi Matematis. Diunduh dari situs http://staff. uny.ac.id/sites/default/files/penelitian/AliMahmudi, pada tanggal 6 november 2013.

Mulyana, Endang.(2009). Pengaruh Model Pembelajaran Matematika Knisley Terhadap Peningkatan
Pemahaman dan Disposisi Matematika Siswa SMA Program IPA. Disertasi UPI. Bandung. Tidak Diterbitkan.

Muslim, A.P. 2013. Peningkatan Kemampuan Presentasi Dan Disposisi Matematis Siswa SMP Melalui Penerapan Thingking Aloud Pair Problem Solving Disertai Hypnoteching(Hypno-Tapps). Universitas Pendidikan Indonesia. http:// repository.upi. edu/477/. (diunduh 21 Desember 2013).

National Council of Teachers of Mathematics (1989). Curriculum and Evaluation Standards for School Mathematics. VA: NCTM Inc.

Purwanto. 2013. Evaluasi Hasil Belajar. Yogyakarta: Pustaka Pelajar.

Rosalin, E. 2008. Gagasan Merancang Pembelajaran Kontekstual. Bandung: PT Karsa Mandiri Persada.

Tiro, M Arif \& Baharuddin Ilyas. 2010. StatistikaTerapan. Makassar: Andira Publisher. 